\title{
Avaliação das Respostas dos Músculos Orbicular Ocular, Adutor do Polegar e Flexor do Hálux à Estimulação com a Seqüência de Quatro Estímulos *
}

\author{
Evaluation of Orbicularis Oculi, Adductor Pollicis and \\ Flexor Hallux Muscles Responses to Train of Four Stimulation
}

Rogean Rodrigues Nunes, TSA

\section{RESUMO}

Nunes RR - Avaliação das Respostas dos Músculos Orbicular Ocular, Adutor do Polegar e Flexor do Hálux à Estimulação com a Seqüência de Quatro Estímulos

Justificativa e Objetivos - O advento de drogas bloqueadoras neuromusculares foi um grande marco na Anestesiologia. Entretanto, um dos problemas do uso desses fármacos é a possibilidade de curarização residual no pós-operatório. 0 objetivo deste estudo foi avaliar as respostas de três músculos à estimulação com seqüência de quatro estímulos durante a instalação e a regressão do relaxamento muscular induzido pelo rocurônio.

Método - Participaram do estudo 30 pacientes do sexo feminino, com idades entre 20 e 40 anos, estado físico ASA I, submetidos à anestesia geral. Na sala de operação, todas receberam alfentanil $10 \mu \mathrm{g} . \mathrm{kg}^{-1}$ i.v. e, em seguida, foram determinadas as respostas supramaximais dos músculos orbicular ocular, adutor do polegar e flexor do hálux com acelerometria. A indução constou de propofol 3,5 mg. $\mathrm{kg}^{-1}$ i.v. e alfentanil $50 \mu \mathrm{g} . \mathrm{kg}^{-1}$ i.v. Todas receberam rocurônio $0,6 \mathrm{mg} \cdot \mathrm{kg}^{-1} \mathrm{i} . \mathrm{v}$. e sevoflurano para a manutenção da anestesia. Foram avaliadas as respostas musculares à estimulação com a seqüência de quatro estímulos a cada 14 segundos, durante instalação e na recuperação T4/T1 de 0,25, 0,50,0,75 e 0,90. A intubação foi realizada no momento de relaxamento mais rápido nos músculos estudados e avaliada por escala proposta.

Resultados - O início de ação nos músculos orbicular ocular, adutor do polegar e flexor do hálux foi respectivamente 64,8 , 131,3 e 196,1 segundos (média). A recuperação até T4/T1 0,9 foi de 59,1, 96,4, 65,4 minutos (média) para os mesmos músculos respectivamente. As condições de intubação traqueal foram consideradas como clinicamente excelentes.

Conclusões - Os resultados mostram que se pode conseguir condições satisfatórias de intubação traqueal com início de ação baseado na resposta à neuroestimulação do músculo orbicular ocular. Entretanto, durante a recuperação do bloqueio, o que proporciona maior margem de segurança é a monitorização do músculo adutor do polegar.

\footnotetext{
* Recebido do (Received from) Serviço de Anestesiologia do Hospital São Lucas de Cirurgia e Anestesia, Fortaleza, CE; Trabalho vencedor do Prêmio Heli Vieira - 2000

1. Diretor Clínico e Chefe do Serviço de Anestesiologia do Hospital São Lucas de Cirurgia e Anestesia
}

Apresentado (Submitted) em 14 de setembro de 2000

Aceito (Accepted) para publicação em 01 de fevereiro de 2001

Correspondência para (Mail to):

Dr. Rogean Rodrigues Nunes

Av. Santos Dumont, 7797/1201 - Bloco Dunas - Papicu

60190-800 Fortaleza, CE

(C) Sociedade Brasileira de Anestesiologia, 2001
UNITERMOS - BLOQUEADORES NEUROMUSCULARES, Não despolarizante: rocurônio; INTUBAÇÃO TRAQUEAL; MONITORIZAÇÃO: função neuromuscular; TÉCNICAS DE MEDIÇÃO: aceleromiografia

\section{SUMMARY}

Nunes RR - Evaluation of Orbicularis Oculi, Adductor Pollicis and Flexor Hallux Muscles Responses to Train of Four Stimulation

Background and Objectives - Neuromuscular blockers (NMB) were a landmark in the practice of anesthesiology. However, one of the problems related to the use of NMBs is postoperative residual curarization. This study aimed at comparing responses of three different muscles to the train of four stimulation during induction and regression of rocuronium-induced neuromuscular blockade.

Methods - Participated in this study 30 women physical status ASA I, aged 20 to 40 years submitted to general anesthesia. In the operating room patients were sedated with intravenous 10 $\mu \mathrm{g} \cdot \mathrm{kg}^{-1}$ alfentanil and supramaximal responses of orbicularis oculi, adductor pollicis and adductor hallucis were obtained. Anesthesia was then induced with intravenous propofol (3.5 $\left.\mathrm{mg} \cdot \mathrm{kg}^{-1}\right)$ and alfentanil $\left(50 \mu \mathrm{g} \cdot \mathrm{kg}^{-1}\right)$. All patients received intravenous rocuronium (0.6 mg. $\mathrm{kg}^{-1}$ ) and sevoflurane for the maintenance of anesthesia. Train of four responses of different muscles were evaluated at every 14 seconds during installation and recovery $T 4 / T 1$ of $0.25,0.50,0.75$ and 0.90 . Intubation was performed at the fastest relaxation moment of studied muscles and was evaluated by the proposed scale.

Results - Mean onset of action for orbicularis oculi, adductor pollicis and adductor hallucis was $64.8,131.3$ and 196.1 seconds, respectively. Mean recovery time of T4/T1 0.9 was 59.1, 96.4 and 65.4, respectively. Tracheal intubation conditions were considered excellent in all cases.

Conclusions - Our results showed that satisfactory conditions for tracheal intubation can be achieved based the orbicularis oculi response to the train of four stimulation. However, during recovery, the highest safety margin was obtained with the adductor pollicis monitoring.

KEY WORDS - MEASUREMENT TECHNIQUES: acceleromyography; MONITORING: neuromuscular function; TRACHEAL INTUBATION; NEUROMUSCULAR BLOCKERS, Nondepolarizing: rocuronium

\section{INTRODUÇÃO}

advento de drogas bloqueadoras neuromusculares (BNM) foi um grande marco na Anestesiologia. Entretanto, um dos problemas do uso desses fármacos é a possibilidade de curarização residual no pós-operatório. Além disso, o tempo certo para proceder-se à intubação traqueal 
obtendo o maior relaxamento de estruturas musculares da laringe e faringe deve ser mensurado para que esta manobra seja realizada de maneira mais tranqüila. Harrison ${ }^{1}$ relatou vários casos de insuficiência respiratória decorrentes da recuperação inadequada do bloqueio neuromuscular e posteriormente outros autores mostraram que 65 óbitos relacionados à anestesia eram devidos a complicações respiratórias pós-operatórias ${ }^{2}$. A monitorização da transmissão neuromuscular, além de sugerir o melhor momento para a intubação traqueal, é o único método seguro para avaliar a ação residual de BNM

O objetivo deste estudo foi avaliar a transmissão neuromuscular através da seqüência de quatro estímulos (SQE) empregando-se a aceleromiografia ${ }^{3,4}$, como monitorização, em três músculos diferentes: orbicular ocular (estimulação do nervo facial); adutor do polegar (estimulação do nervo ulnar) e flexor do hálux (estimulação do nervo tibial posterior). Foram analisadas as condições de intubação orotraqueal realizada no tempo de mais rápido relaxamento muscular entre os músculos estudados, assim como o perfil de recuperação dos três músculos estudados com o emprego do rocurônio.

\section{MÉTODO}

Após aprovação do protocolo pela Comissão de Ética da Instituição e o consentimento formal dos pacientes, foram incluídos neste estudo 30 pacientes do sexo feminino, com idades entre 20 e 40 anos, índice biomassa entre 22 e 28 , estado físico ASA I, todas Mallampati l e com extensão normal da cabeça, submetidas a cirurgias eletivas sob anestesia geral. Foram excluídas do estudo pacientes com doença neuromuscular, hepática, renal ou aquelas que fizessem uso de drogas que interferissem na transmissão neuromuscular. Nenhuma das pacientes fez uso de qualquer medicação pré-anestésica.

Na sala de operação, foi feita monitorização com cardioscópio em duas derivações ( $D_{\|}$e V5), oximetria de pulso, capnografia, analisador de gases anestésicos, pressão arterial não invasiva automática, freqüência de margem espectral 95\% (mantida entre 8 e 12) e BIS (entre 40 e 50). Foi feita punção venosa, que foi mantida com solução de Ringer com lactato $(500 \mathrm{ml})$ e injetado alfentanil $\left(10 \mu \mathrm{g} . \mathrm{kg}^{-1} \mathrm{i} . \mathrm{v}\right.$. $)$. A seguir foram determinadas simultaneamente as respostas supramaximais e basais à SQE dos músculos orbicular ocular, adutor do polegar e flexor do hálux, aplicando-se eletrodos estimuladores no trajeto dos nervos facial, ulnar e tibial posterior (Figuras 1, 2 e 3).

Após pré-oxigenação durante cinco minutos, utilizou-se, por via venosa, propofol $\left(3,5 \mathrm{mg} \cdot \mathrm{kg}^{-1}\right)$, alfentanil $\left(50 \mu \mathrm{g} \cdot \mathrm{kg}^{-1}\right)$ e rocurônio $\left(0,6 \mathrm{mg} \mathrm{kg}^{-1}\right)$ em 5 segundos ${ }^{5}$. Simultaneamente foram feitas estimulações nos três nervos referidos. A anestesia foi mantida com sevoflurano, com concentração expirada ajustada para obter um índice bispectral (BIS) entre 40 e 50. Todos os pacientes foram ventilados com volume corrente de $8 \mathrm{ml} . \mathrm{kg}^{-1}$, através de ventilador com compensação de perda de complacência em sistema respiratório circular com reab-

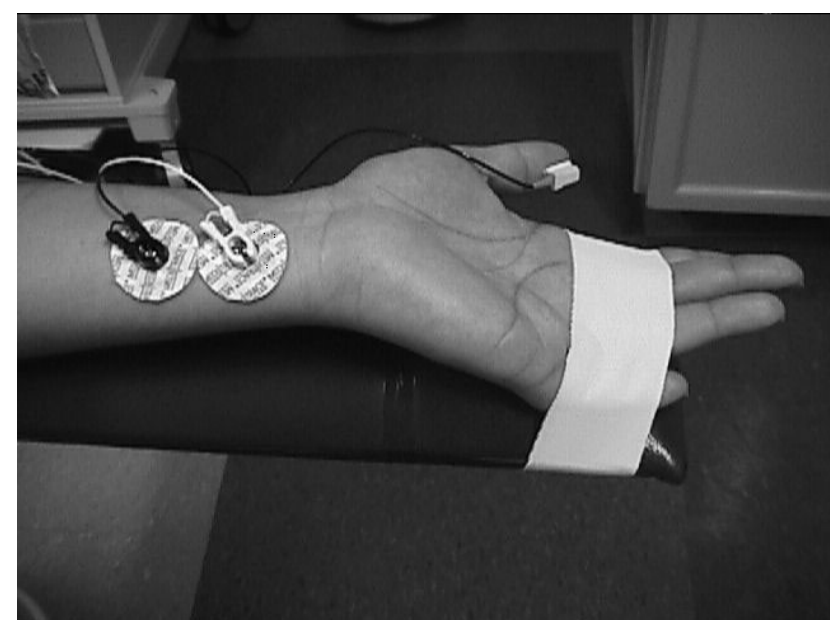

Figura 1 - Neuroestimulação do Nervo UInar e Avaliação do Músculo Adutor do Polegar

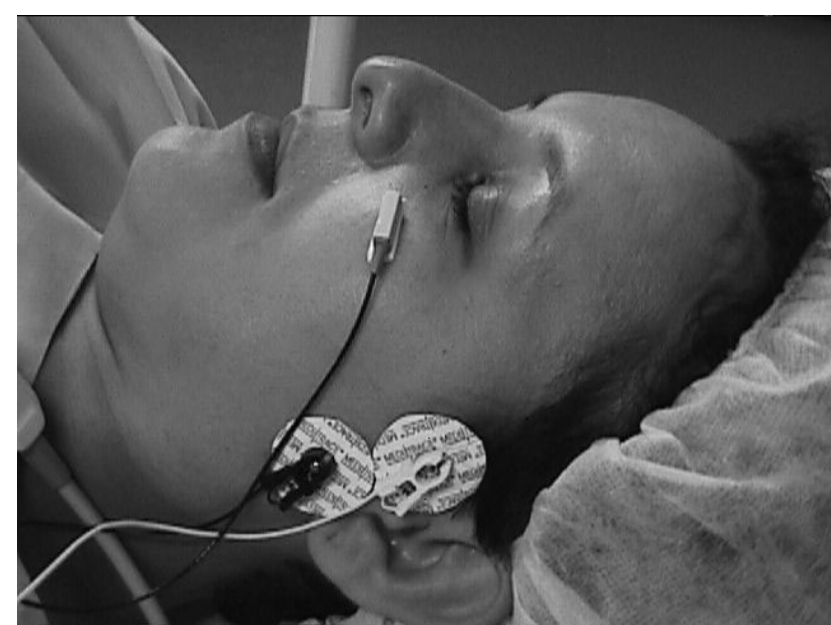

Figura 2 - Eletrodos Estimuladores no Nervo Facial e Avaliação da Contração do Músculo Orbicular Ocular

sorvedor de $\mathrm{CO}_{2}$, com relação I/E de 1:2. Em todos as pacientes a temperatura corporal (naso-faríngea) foi mantida entre 36 e $37^{\circ} \mathrm{C}$, com auxílio de lençol de ar térmico forçado convectivo.

Foram avaliados o início de ação em cada ponto estimulado, sendo este considerado como o tempo decorrido entre o início da injeção do rocurônio, até queda de $95 \%$ de T1 $(\text { T1 } 15 \%)^{5}$, assim como o tempo para recuperação de T4/T1 em 0,25, 0,50, 0,75 e 0,90 nos três músculos. Foi verificado também o valor de T4/T1 do último ponto a recuperar em relação ao penúltimo, quando este atingiu 0,9. A laringoscopia e intubação traqueal foram procedidas após o primeiro músculo apresentar T1 $5 \%$, baseando-se no ponto mais rápido de decaimento da transmissão neuromuscular. As condições de intubação traqueal foram analisadas através da escala apresentada no quadro I. 
Quadro I - Condições de Intubação Traqueal ${ }^{5}$

\begin{tabular}{llll}
\hline & & Clinicamente aceitáveis & Clinicamente inaceitáveis \\
\hline - Variáveis & Excelente & Boa & Ruim \\
- Laringoscopia & Fácil & Regular & Difícil \\
- Cordas vocais & & Intermediária & Fechada \\
Posição & Abduzida & Presente & Em fechamento \\
Movimentação & Nenhuma & Pequeno & Vigoroso \\
- Reação ao tubo/balonete & & Mov. diafragmática & Mov. Diafragmática sustentada \\
Movimento de membro inferior & Ausente & Ausente &
\end{tabular}

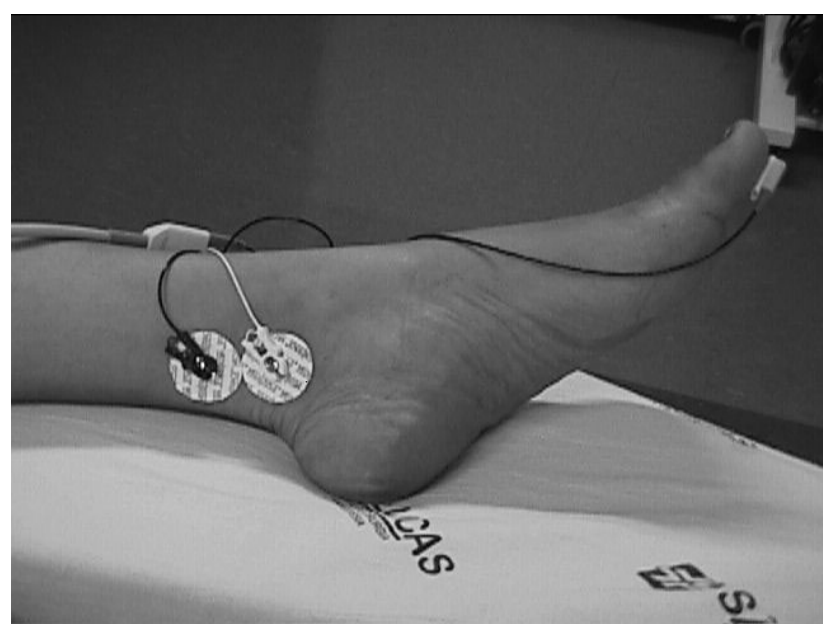

Figura 3 - Eletrodos Estimuladores sobre o Nervo Tibial Posterior e Avaliação do Músculo Flexor Curto do Hálux

As condições de intubação traqueal foram avaliadas como:

- Excelentes: todas qualificações excelentes;

- Boas: qualificações excelentes ou boas;

- Ruins: presença de uma qualificação listada como ruim.

As laringoscopias foram classificadas como:

- Fácil: mandíbula relaxada, ausência de resistência à lâmina do laringoscópio;

- Regular: relaxamento mandibular incompleto, discreta resistência à lâmina do laringoscópio;

- Difícil: relaxamento mandibular insuficiente, resistência ativa do paciente à laringoscopia.

Os dados foram avaliados estatisticamente através da análise de Variância e posterior aplicação do teste de Tukey, considerando-se como significativo valor de $p$ menor que $5 \%$.

\section{RESULTADOS}

A tabela I mostra os dados demográficos da população estudada. Em relação ao início de ação (T1 5\%), houve diferença estatisticamente significativa entre os três músculos avalia- dos, como mostra a tabela II, sendo T1 $5 \%$ para o orbicular ocular o mais rápido em todas as marcações de tempo ( $p<$ $0,05)$. A recuperação do bloqueio neuromuscular, do músculo orbicular ocular foi mais rápida em relação a todos os tempos, sendo significativa estatisticamente a diferença comparando-se ao segundo mais rápido (polegar ou hálux). Em relação a T4/T1, a partir do valor 0,50 o músculo flexor do hálux mostrou recuperação espontânea mais rápida do que a observada para o músculo adutor do polegar (Tabela III e Figura 4). Quando o músculo flexor do hálux apresentava T4/T1 de 0,9, o valor dessa relação para o músculo adutor do polegar mostrava-se de $0,55 \pm 0,03(p<0,001)$. Quanto às condições de intubação traqueal, todas foram consideradas excelentes.

Tabela I - Dados Demográficos

\begin{tabular}{ll}
\hline Variáveis & Média $\pm \mathrm{DP}$ \\
\hline Idade & $30,65 \pm 5,26$ \\
Peso & $61,1 \pm 3,93$ \\
Índice biomassa & $25,4 \pm 1,23$ \\
\hline
\end{tabular}

Tabela II - Início de Ação do Bloqueio Neuromuscular (T1 5\%) nos Músculos Estudados

\begin{tabular}{lc} 
Músculos & Média $\pm \mathrm{DP}$ (segundos) \\
\hline Orbicular ocular & $64,80 \pm 2,09$ * \\
Adutor do polegar & $131,35 \pm 26,59$ * \\
Flexor do hálux & $196,20 \pm 8,64$ * \\
\hline
\end{tabular}
${ }^{*} p<0,05$

Tabela III - Tempo (minutos) para Recuperação de T4/T1 (Média \pm DP)

\begin{tabular}{lclc}
\hline SQE T4/T1 & \multicolumn{3}{c}{ Músculo } \\
\hline & $\begin{array}{c}\text { Orbicular } \\
\text { ocular }\end{array}$ & $\begin{array}{c}\text { Adutor do } \\
\text { polegar }\end{array}$ & $\begin{array}{c}\text { Flexor do } \\
\text { hálux }\end{array}$ \\
\hline 0,25 & $39,7 \pm 1,4^{*}$ & $44,6 \pm 1,4$ & $45,6 \pm 2,0$ \\
0,50 & $47,6 \pm 1,5^{*}$ & $56,4 \pm 1,1^{*}$ & $52,7 \pm 1,5^{*}$ \\
0,75 & $53,0 \pm 1,7^{*}$ & $74,6 \pm 4,5^{*}$ & $59,4 \pm 2,7$ * \\
0,90 & $59,1 \pm 1,3^{*}$ & $96,4 \pm 2,0 *$ & $65,4 \pm 3,2$ * \\
\hline
\end{tabular}

${ }^{*} p<0,05$

\section{DISCUSSÃo}

Os bloqueadores neuromusculares são largamente utilizados em anestesia e terapia intensiva por facilitar a intubação 


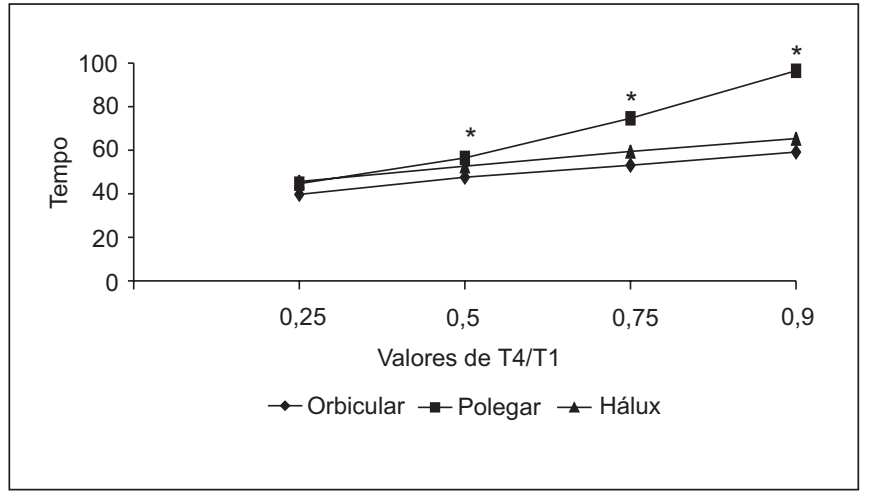

Figura 4 - Tempo Médio (min) para atingir Valores de T4/T1 nos Músculos Estudados, durante a Recuperação do Bloqueio $\mathrm{Ne}-$ uromuscular

${ }^{*} p<0,05$ entre todos os tempos

traqueal, causar melhor relaxamento do campo operatório e permitir adequado manuseio de pacientes sob ventilação mecânica. Entretanto, podem promover importantes complicações no pós-operatório por bloqueio neuromuscular residual ${ }^{6,7}$.

O conceito de que existe recuperação satisfatória do bloqueio neuromuscular, quando o paciente apresenta T4/T1 em torno de 0,70 , foi por mais de 20 anos considerado como adequado. No entanto, recentemente foi demonstrado que uma T4/T1 nestes valores não representa recuperação completa, podendo ocorrer depressão da resposta ventilatória à hipóxia $^{8-10}$. Viby-Mogensen e col. ${ }^{11}$ mostraram que $25 \%$ dos pacientes não monitorizados em relação à função neuromuscular no per-operatório eram admitidos na sala de recuperação sem conseguir manter a cabeça elevada por 5 segundos e $42 \%$ apresentavam T4/T1 menor que 0,7. Estudo recente ${ }^{12}$ avaliando e correlacionando a T4/T1 com sinais e sintomas em pacientes acordados mostrou que a capacidade para manter a cabeça elevada durante 5 segundos não ocorre até que esse valor atinja 0,60 e que, quando T4/T1 é menor do que 0,9 há ainda nítidos sinais de paralisia residual, como a diplopia e a dificuldade de acompanhar objetos em movimento. Assim, aceita-se hoje que haja uma recuperação satisfatória da função neuromuscular quando T4/T1 é igual ou maior do que 0,90 .

Os nossos resultados mostraram que se pode conseguir condições satisfatórias de intubação orotraqueal, baseando-se na monitorização do músculo orbicular ocular (64,8 segundos - média), já que tais condições apresentaram-se excelentes quando foi obtido T1 $5 \%$, refletindo a melhor correlação com a resposta diafragmática. Estudos ${ }^{13,14}$ mostraram que o relaxamento do músculo orbicular ocular se estabelece em tempo similar à musculatura da laringe; assim, como a monitorização dos músculos da laringe é tecnicamente mais difícil, costuma-se empregar o músculo orbicular ocular como guia para a escolha do melhor momento para a intubação traqueal. Nossos resultados clínicos corroboram essas observações experimentais.
O presente trabalho apontou uma recuperação muscular sempre mais rápida para o músculo orbicular ocular, dado já registrado na literatura ${ }^{15}$.

O tempo para T4/T1 atingir 0,25 foi similar para os músculos adutor do polegar e flexor do hálux (em torno de 45 minutos). Registros na literatura com o vecurônio são diferentes e mostram recuperação precoce no músculo adutor do polegar ${ }^{16}$.

Com o evoluir da recuperação espontânea, registramos que o músculo adutor do polegar foi o que mais demorou para a T4/T1 atingir 0,9. Esses dados vêm ao encontro de outras observações que igualmente registraram regressão mais demorada para o músculo adutor do polegar.

Conclui-se que a intubação traqueal baseando-se no tempo do relaxamento do músculo orbicular ocular foi obtida com sucesso e com condições satisfatórias em todas as pacientes, e que o músculo adutor do polegar deve ser o preferido para a aferição da regressão do relaxamento muscular.

\section{AGRADECIMENTO}

A realização deste trabalho deveu-se ao apoio e incentivo continuamente prestados pelo Diretor Presidente do Hospital São Lucas de Cirurgia e Anestesia, Dr. Salustiano Gomes de Pinho Pessoa.

\section{Evaluation of Orbicularis Oculi, Adductor Pollicis and Flexor Hallux Muscles Responses to Train of Four Stimulation}

Rogean Rodrigues Nunes, M.D.

\section{INTRODUCTION}

The advent of neuromuscular blockers (NMB) were a landmark in the practice of anesthesiology. However, one of the problems related to the use of NMBs is postoperative residual curarization. In addition, the right time for performing tracheal intubation with the best relaxation of laryngeal and pharyngeal muscles should be measured to make easier such maneuver. Harrison ${ }^{1}$ has reported several respiratory failure cases due to inadequate recovery of neuromuscular blocks, and afterwards other authors have shown that 65 anesthesia-related deaths were due to postoperative respiratory complications ${ }^{2}$. Neuromuscular transmission monitoring, in addition to suggesting the best tracheal intubation time, is the only safe method to evaluate NMBs residual action.

This study aimed at evaluating neuromuscular transmission through the Train of Four Stimulation (TOF) using acceleromyography ${ }^{3,4}$ to monitor three different muscles: orbicularis oculi (facial nerve stimulation); adductor pollicis (ulnar nerve 
stimulation) and flexor hallux (posterior tibial nerve stimulation). Tracheal intubation performed at the fastest muscle relaxation time among studied muscles and their recovery profile with the use of rocuronium were evaluated.

\section{METHODS}

After the Hospital's Ethics Committee approval and their formal consent, participated in this study 30 female patients, aged 20 to 40 years, biomass index between 22 and 28 , physical status ASA I, all of them Mallampati I and with normal extension of the head, submitted to elective surgeries under general anesthesia. Patients with neuromuscular, liver and renal diseases and those using drugs interfering with neuromuscular transmission were excluded from the study. No patient was premedicated.

Monitoring was performed in the operating room with cardioscope in $D_{\|}$and $V_{5}$, pulse oximetry, capnography, anesthetic gases analyzer, non invasive blood pressure, 95\% spectral margin frequency (maintained between 8 and 12) and BIS (between 40 and 50). A venous puncture was obtained and maintained with lactated Ringer's $(500 \mathrm{ml})$ and intravenous alfentanil was injected $\left(10 \mu \mathrm{g} . \mathrm{kg}^{-1}\right)$. Then, supramaximal and baseline TOF responses of orbicularis oculi, adductor pollicis and flexor hallux were simultaneously obtained by applying stimulating electrodes on facial, ulnar and posterior tibial nerve paths (Figures 1, 2 and 3).

After a five-minute preoxygenation, intravenous propofol $\left(3.5 \mathrm{mg} \cdot \mathrm{kg}^{-1}\right)$, alfentanil $\left(50 \mu \mathrm{g} . \mathrm{kg}^{-1}\right)$ and rocuronium $(0.6$ $\left.\mathrm{mg} \cdot \mathrm{kg}^{-1}\right)$ were injected in five seconds ${ }^{5}$. At the same time, the three nerves were stimulated. Anesthesia was maintained with sevoflurane and expired concentration was adjusted to obtain a bispectral index (BIS) between 40 and 50. All patients were ventilated with a tidal volume of $8 \mathrm{ml}^{.} \mathrm{kg}^{-1}$, through a ventilator with compliance loss compensation in a circular respiratory system with $\mathrm{CO}_{2}$ reabsorber and an I/E ratio of $1: 2$. Body temperature (naso-pharyngeal) was maintained between 36 and $37^{\circ} \mathrm{C}$ with the aid of a forced convective air thermal blanket.

Onset of action in all stimulated points was evaluated and this was considered the time elapsed between the beginning of rocuronium injection and $95 \%$ decrease in T1 $(\mathrm{T} 1=5 \%)^{5}$, as well as recovery time for T4/T1 in $0.25,0.50,0.75$ and 0.90 for the three muscles. The value of $\mathrm{T} 4 / \mathrm{T} 1$ from the last point to re-

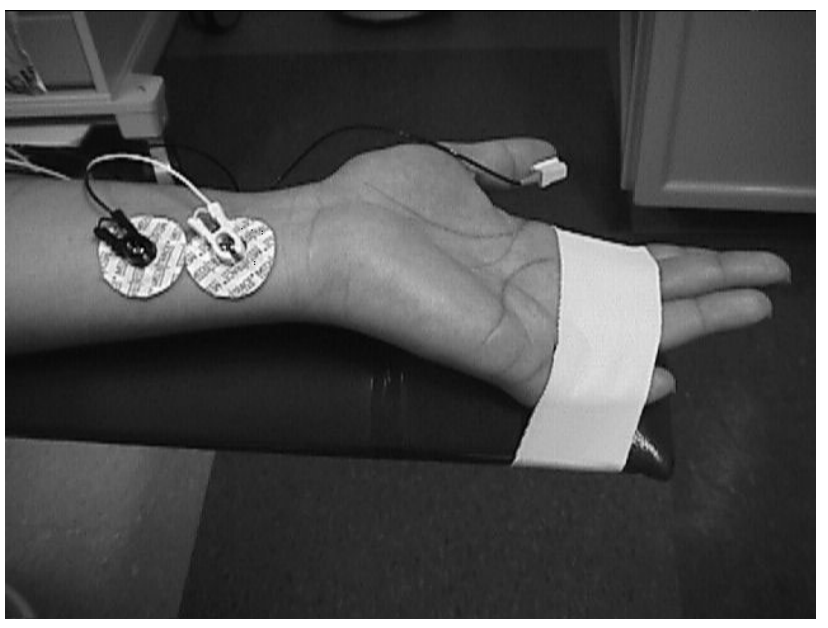

Figure 1 - Ulnar Nerve Stimulation and Adductor Pollicis Evaluation

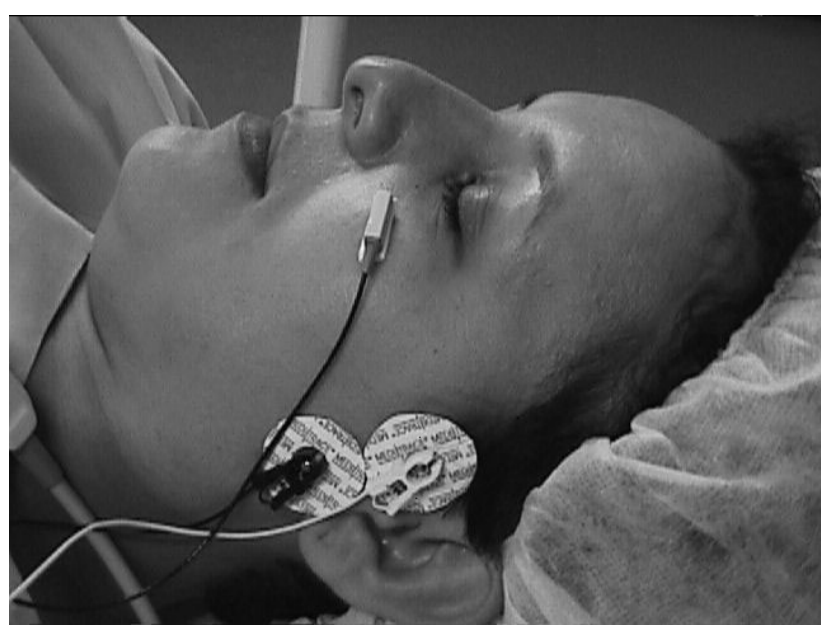

Figure 2 - Stimulating Electrodes on the Facial Nerve and Orbicularis Oculi Contraction Evaluation

cover as compared to the one before last when it reached 0.9 was also evaluated. Laryngoscopy and tracheal intubation were performed when the first muscle showed T1 $=5 \%$, based on the fastest decay point of neuromuscular transmission. Tracheal intubation conditions were analyzed through the scale shown in chart I.

Chart I - Tracheal Intubation Conditions ${ }^{5}$

\begin{tabular}{llll}
\hline & & Clinically accepted & Clinically unacceptable \\
\hline - Variables & Excellent & Good & Poor \\
- Laryngoscopy & Easy & Regular & Difficult \\
- Vocal Cords & & & Closed \\
Position & Abducted & Intermediate & Closing \\
Movement & None & Present & Strong \\
- Reaction to Probe/Cuff & & Weak & Sustained diaphragmatic movement \\
Lower limb movement & Absent & Absent & Diaphragmatic movement
\end{tabular}




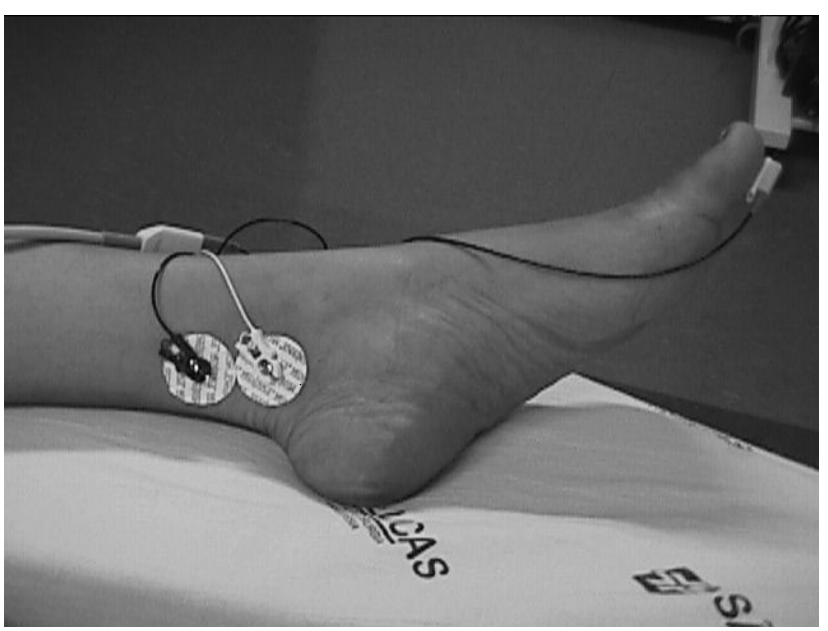

Figure 3 - Stimulating Electrodes on the Posterior Tibial Nerve and Flexor Hallux Evaluation

Tracheal intubation conditions were evaluated as:

- Excellent: all qualifications excellent;

- Good: qualifications excellent or good;

- Poor: presence of one qualification listed as poor.

Laryngoscopies were evaluated as:

- Easy: relaxed mandible, lack of resistance to the laryngoscope blade;

- Regular: incomplete mandible relaxation, mild resistance to the laryngoscope blade;

- Difficult: insufficient mandible relaxation, patient's active resistance to laryngoscopy.

Data were statistically analyzed by analysis of variance followed by Tukey's test, considering significant $p<5 \%$.

\section{RESULTS}

Table I shows demographic data. As to onset of action ( $\mathrm{T} 1=$ $5 \%$ ), there has been a statistically significant difference among the three evaluated muscles, as shown in table II, being T1 $=5 \%$ for the orbicularis oculi the fastest in all measurements $(p<0.05)$. Orbicularis oculi neuromuscular block recovery time was the shortest as compared to all times with a statistically significant difference as compared to the second shortest (thumb or toe). As to T4/T1 ratio, as from 0.50 , flexor hallux had the fastest spontaneous recovery as compared to adductor pollicis (Table III and Figure 4). When flexor hallux showed a T1/T4 of 0.9 , the value of this ratio for the adductor pollicis was $0.55 \pm 0.03(p<0.001)$. All tracheal intubations were considered excellent.
Table I - Demographics Data

\begin{tabular}{lc}
\hline Variables & Mean \pm SD \\
\hline Age & $30.65 \pm 5.26$ \\
Weight & $61.1 \pm 3.93$ \\
Biomass Index & $25.4 \pm 1.23$ \\
\hline
\end{tabular}

Table II - Neuromuscular Block Onset of Action (T1 5\%) in Studied Muscles

\begin{tabular}{lc}
\hline Muscles & Mean \pm SD (seconds) \\
\hline Orbicularis oculi & $64.80 \pm 2.09$ * \\
Adductor Pollicis & $131.35 \pm 26.59$ * \\
Adductor Hallucis & $196.20 \pm 8.64$ * \\
\hline
\end{tabular}

${ }^{*} p<0,05$

Table III - Time (minutes) for T4/T1 Recovery (Mean \pm SD)

\begin{tabular}{llll}
\hline TOF T4/T1 & \multicolumn{3}{c}{ Muscle } \\
\hline & $\begin{array}{c}\text { Orbicularis } \\
\text { Oculi }\end{array}$ & $\begin{array}{c}\text { Adductor } \\
\text { Pollicis }\end{array}$ & $\begin{array}{c}\text { Flexor } \\
\text { Hallux }\end{array}$ \\
\hline 0.25 & $39.7 \pm 1.4^{*}$ & $44.6 \pm 1.4$ & $45.6 \pm 2.0$ \\
0.50 & $47.6 \pm 1.5^{*}$ & $56.4 \pm 1.1^{*}$ & $52.7 \pm 1.5^{*}$ \\
0.75 & $53.0 \pm 1.7^{*}$ & $74.6 \pm 4.5^{*}$ & $59.4 \pm 2.7^{*}$ \\
0.90 & $59.1 \pm 1.3^{*}$ & $96.4 \pm 2.0^{*}$ & $65.4 \pm 3.2^{*}$ \\
\hline
\end{tabular}

* $p<0,05$

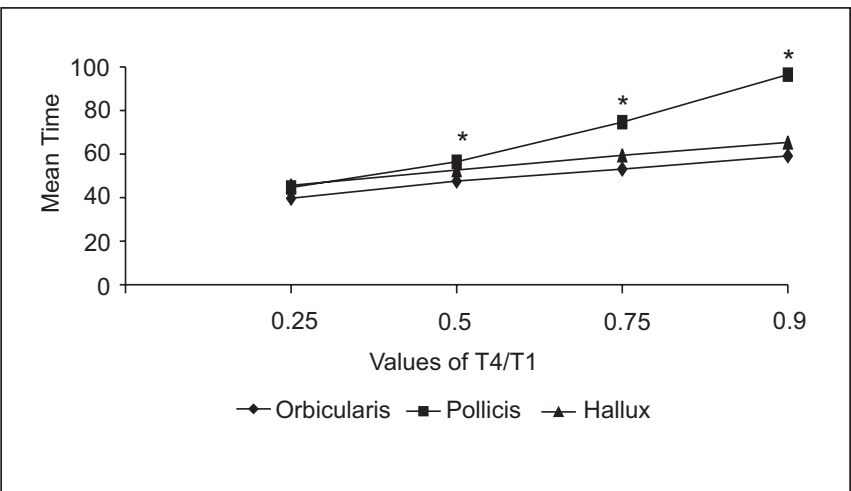

Figure 4 - Mean time (minutes) to Reach T4/T1 Values in Studied Muscles during Neuromuscular Block Recovery

$* p<0.05$ among all times

\section{DISCUSSION}

Neuromuscular blockers are widely used in anesthesia and intensive care units for helping tracheal intubation, promoting a better surgical field relaxation and allowing for an adequate handling of patients under mechanical ventilation. However, they may promote major postoperative complications due to residual neuromuscular blockade ${ }^{6,7}$.

For more than 20 years, the concept of a satisfactory neuromuscular block recovery when the patient had a T1/T4 around 0.70 has been considered adequate. However, it has been recently shown that a T1/T4 around such value does not 
represent a total recovery and may lead to ventilatory response depression to hypoxia ${ }^{8-10}$. Viby-Mogensen et al. ${ }^{11}$ have shown that $25 \%$ of patients with no monitoring of perioperative neuromuscular functions were admitted to the recovery room unable to keep their heads up for 5 seconds and $42 \%$ presented with a T4/T1 lower than 0.7 . A recent study ${ }^{12}$ evaluating and correlating T4/T1 with signs and symptoms in awaken patients has shown that there is no ability to maintain the head up for 5 seconds until such value reaches 0.60 , and that when T4/T1 is lower than 0.9 there are clear signs of residual paralysis, such as diplopia and difficulty to follow moving objects. So, today it is accepted that there is a satisfactory neuromuscular function recovery when T4/T1 is equal to or higher than 0.90 .

Our results have shown that it is possible to attain satisfactory tracheal intubation conditions based on the monitoring of the orbicularis oculi (mean - 64.8 seconds), since such conditions were already excellent when $\mathrm{T} 1=5 \%$, reflecting a better correlation with the diaphragmatic response. Studies ${ }^{13,14}$ have shown that orbicularis oculi relaxation is established in a time similar to the relaxation of the larynx muscles; since monitoring larynx muscles is technically more difficult, orbicularis oculi is in general used as a guide for the best moment for tracheal intubation. Our clinical results confirm such experimental observations.

Our study has shown a muscle recovery consistently faster for the orbicularis oculi, which is in line with the literature ${ }^{15}$.

Time for T4/T1 to reach 0.25 was similar for adductor pollicis and flexor hallux (around 45 minutes). Reports in the literature with the use of vecuronium are different and show an early recovery of the adductor pollicis ${ }^{16}$.

With the evolution of spontaneous recovery, we observed that the adductor pollicis took longer for T4/T1 to reach 0.9 . Such data are in line with other observations which have also shown a slower regression for the adductor pollicis.

Our conclusion is that tracheal intubation based on orbicularis oculi relaxation time has been successful and with satisfactory conditions for all patients, and that the adductor pollicis should be the muscle of choice to check muscle relaxation regression.

\section{ACKNOWLEDGEMENT}

This study was made possible by the continuous support and encouragement of the President Director of Hospital São Lucas de Cirurgia e Anestesia, Dr. Salustiano Gomes de Pinho Pessoa.

\section{REFERÊNCIAS - REFERENCES}

01. Harrison GG - Death attributable to anesthesia. $\mathrm{Br} J$ Anaesth, 1978;50:1041-1046.

02. Tiret L, Desmonts JM, Hatton F et al - Complications associated with anesthesia: a prospective survey in France. Can Anaesth Soc J, 1986;33:336-344.

Revista Brasileira de Anestesiologia

Vol. 51, № 4, Julho - Agosto, 2001
03. Viby-Mogensen J, Jensen E, Werner M et al - Measurement of acceleration: a new method of monitoring neuromuscular function. Acta Anaesthesiol Scand, 1988;32:45-48.

04. Rupp SM - Monitorização do Bloqueio Neuromuscular. Clin Anestesiol Am N , 1993; 347-363.

05. Viby-Mogensen J, Engbaek J, Eriksson LI et al - Good clinical research practice (GCRP) in pharmacodynamic studies of neuromuscular blocking agents. Acta Anaesthesiol Scand, 1996;40:59-74.

06. Kopman AF, Zank LM, Neuman GG et al - Residual postoperative paralysis. Anesthesiology, 1996;85:1253-1259.

07. Lennmarken C, Lofstrom JB - Partial curarization in the postoperative period. Acta Anaesthesiol Scand, 1984;28:260-262.

08. Ali HH, Wilson RS, Savarese JJ et al - The effect of tubocurarine on indirectly elicited train-of-four muscle response and respiratory measurements in humans. Br J Anaesth, 1975;47:570-574.

09. Brull SJ, Silverman DG - Visual and tactile assessment neuromuscular fade. Anesth Analg, 1993;77:352-355.

10. Eriksson LI - Reduced hypoxic chemosensitivy in partially paralysed man. A new property of muscle relaxants. Acta Anaesthesiol Scand, 1996;40:520-523.

11. Viby-Mogensen J, Jorgensen BC, Ording H - Residual curarization in the recovery room. Anesthesiology, 1979;50:539-541.

12. Kopman AF, Yee PS, Neuman GG - Relationship of the train-of-four fade ratio to clinical signs and symptoms of residual paralysis in awake volunteers. Anesthesiology, 1997;86: 765-771.

13. Donati F, Meistelman C, Plaud B - Vecuronium neuromuscular blockade at the diaphragm, the orbicularis oculi, and adductor pollicis muscles. Anesthesiology, 1990;73:870-875.

14. Almeida MCS, Dal Mago AJ, Pederneiras SG - Comparação das condições de Intubação traqueal com diferentes doses de rocurônio, utilizando a monitorização do músculo orbicular ocular. Rev Bras Anestesiol, 1998;48:468-474.

15. Whalley DG, Maurer WG, Knapik Al et al - Comparison of neuromuscular effects, efficacy and safety of rocuronium and atracurium in ambulatory anaesthesia. Can J Anaesth, 1998;45: 954-959.

16. Kitajima T, Ishii K, Kobayashi T et al - Differential effect of vecuronium on the thumb and the big toe muscles evaluated by acceleration measurement. J Anesth , 1994;8:143-145.

\section{RESUMEN}

Nunes RR - Evaluación de las Respuestas de los Músculos Orbicular Ocular, Aductor del Pulgar y Flexor del Hálux a la Estimulación con la Secuencia de Cuatro Estímulos

Justificativa y Objetivos - El adviento de drogas bloqueadoras neuromusculares fue un grande marco en la Anestesiologia. Entretanto, uno de los problemas del uso de eses fármacos es la posibilidad de curarización residual en el pós-operatório. El objetivo de este estudio fue evaluar las respuestas de tres músculos a la estimulación con secuencia de cuatro estímulos durante la instalación y la regresión del relajamiento muscular inducido por el rocuronio.

Método - Participaron del estudio 30 pacientes del sexo femenino, con edades entre 20 y 40 años, estado físico ASA I, sometidas a anestesia general. En la sala de operación todas recibieron alfentanil $10 \mu \mathrm{g} \cdot \mathrm{kg}^{-1}$ i.v. $y$, en seguida fueron determinadas las respuestas supramaximales de los músculos orbicular ocular, aductor del pulgar y flexor del hálux con acelerometria. La inducción constó de propofol 3,5 mg. $\mathrm{kg}^{-1} \mathrm{i}$. v. $y$ alfentanil $50 \mu \mathrm{g} . \mathrm{kg}^{-1}$ i.v. Todas recibieron rocuronio 0,6 $\mathrm{mg} . \mathrm{kg}^{-1} \mathrm{i}$.v. y sevoflurano para la manutención de la anestesia. 
Fueron evaluadas las respuestas musculares a la estimulación con la secuencia de cuatro estímulos a cada 14 segundos, durante instalación y en la recuperación T4/T1 de 0,25, 0,50, 0,75 y 0,90. La intubación fue realizada en el momento de relajamiento más rápido en los músculos estudiados y evaluada por escala propuesta.

Resultados - El inicio de acción en los músculos orbicular ocular, aductor del pulgar y flexor del hálux fue respectivamente $64,8,131,3$ y 196,1 segundos (media). La recuperación hasta T4/T1 0,9 fue de 59,1,96,4, 65,4 minutos (media) para los mismos músculos respectivamente. Las condiciones de intubación traqueal fueron consideradas como clínicamente excelentes.

Conclusiones - Los resultados muestran que se puede conseguir condiciones satisfactorias de intubación traqueal con inicio de acción teniendo como base la respuesta a la neuroestimulación del músculo orbicular ocular. Entretanto, durante la recuperación del bloqueo, lo que proporciona mayor margen de seguridad es la monitorización del músculo aductor del pulgar. 